\title{
Wheat Response to Azospirillum Inoculation, Organic Amendments and Mineral Nitrogen Fertilizer with Application of ${ }^{15} \mathrm{~N}$ Stable Isotope Technique Soliman, M. A. E. \\ Soil Department, Faculty of Agriculture, Damietta University, Egypt dr.mas2015@yahoo.com
}

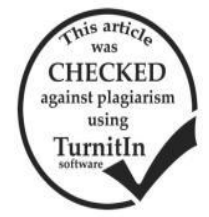

ABSTRACT

Wheat is one of the most important strategic crops needed for food and feeding. Due to its importance, this work aimed to demonstrate the role of organic/mineral $\mathrm{N}$ sources in collaboration with bio-fertilizer inoculation in enhancement of wheat growth and yield under low fertile sand soil with special emphasis to economical and environmental impacts. Field experiment was conducted on sand clay loam soil using wheat (Triticum aestivum L., Sakha 93) exposed to different rates of mineral nitrogen fertilizer either solely or in combination with different rates of organic compost. Fertilization treatments were applied with or without Azospirillum brasilinese as a representative of plant growth promoting rhizobacteria (PGPR). Tested treatments were completely randomly distributed in statistical factorial block design. Application of nitrogen fertilizer at full dose $\left(120 \mathrm{~kg} \mathrm{~N} f e d^{-1}\right)$, induced higher grain yield and nutrient uptake (NPK) than those recorded with other low mineral-N levels. Both plants fully treated with organic compost or in combination with levels of mineral nitrogen achieved grain yield and nutrient acquisition nearly closed to those of moderate mineral-N level. Relatively, inoculation with Azospirillum brasilense resulted in higher grain yield by about $25 \%$ over an un-inoculated plants. Nitrogen uptake by grains and straw significantly increased by increasing nitrogen fertilizer rates and inoculation treatment. Phosphorus and potassium contents not responded to Azospirillum inoculation but enhanced with increasing nitrogen fertilizer rates and application of organic compost. Combined treatments had enhanced nitrogen portion derived by either grains or straw from mineral-N form. Inoculated plants compensated remarkable amounts of nitrogen via $\mathrm{N}_{2}$-fixation. Low amounts of nitrogen released from compost were derived to grains of inoculated and uninoculated plants but it increases with increase of compost component in the combined treatments. Nitrogen use efficiency (NUE) by either grains or straw of the inoculated plants was tended to increase with decreasing $\mathrm{N}$ fertilizer rates either individually or in combination with compost. Application of medium to low mineral $\mathrm{N}$ in combination with organic compost lowered the portion of $\mathrm{N}$ losses and achieved positive $\mathrm{N}$ balance. This phenomenon was more vigorous with combined treatment of $75 \%$ mineral plus $25 \%$ organic compost under the uninoculated treatment. Negative $\mathrm{N}$ balances were observed with sole addition of mineral nitrogen and tended to decline with reduction in nitrogen fertilizer rates. These trends were lower in case of the uninoculated plants than inoculated one.

Keywords: Azospirillum, compost, fertilizer, ${ }^{15} \mathrm{~N}$, N-balance, NUE, wheat.

\section{INTRODUCTION}

It is well established the importance of nitrogen nutrient as a limiting factor for wheat production especially under low to poor fertile soils. Integrated nutrients management, therefor, is the most important recent approach applied in cereal crop production rotation. Similarly, wheat is considered the key of cereal crops (Suwara et al., 2007). Thus, it dependent on the soil fertility and hence on the availability of nutrients to plants, via fertilizers (Filipek and Skowrońska, 2009). Appropriate and adequate soil conditions may help in reserving optimal crop yields (Kaczor and Łaszcz-Zakorczmenna, 2009). The application of organic and mineral fertilizers changes the chemical, physical, and biological soil properties. Amended soil with organic fertilizers could be physically and chemically improved more than that with sole nitrogen fertilizer (Słowińska-Jurkiewicz et al., 2013). In addition, mineral, organic, and biofertilization also stimulates the development of biological excretion of enzymes responsible for nutrients transformations in soils (Krämer and Green, 2000; George et al., 2002; Bielińska and Mocek-Płóciniak, 2012).

As reviewed by Naiman et al., (2009), Azospirillum genus is considered one of the most genera used of plant growth promoting rhizobacteria (PGPR). The potential of this bacterium-plant association to increase crop production was reported earlier. Positive impacts on plant growth through several mechanisms include enhancement of root development, production of growth regulators and nitrogen fixation. In addition, Azospirillum inoculation led to enhance nitrogen, phosphorus, potassium and various micronutrients uptake by inoculated plants (Naiman et al., 2007). Several years ago, a publication compiled data from different countries showing the state-of-the-art in the Azospirillum inoculation responses (Cassán and García de Salamone,
2008). Plant growth promotion was positively affected by coinoculation with Azospirillum spp. and several changes in plant growth parameters may affect the crop production (Creus et al., 2004;Askary, et al., 2008; 2009).

This work aimed to recognize the best strategy of nitrogen fertilization and evaluating the role of asymbiotic bacteria in compensating a part of nitrogen required for wheat production.

\section{MATERIALS AND METHODS}

A field experiment was conducted in the Experimental Farm of Soil and Water Research Department, Nuclear Research Center, Inshas area that belongs to Sharqeia Governorate, Egypt, during winter season of 2013/2014 to follow up the impact of chemical $\mathrm{N}$ fertilization with different rates $(100,75$, and $25 \% \mathrm{~kg} \mathrm{~N}$ fed-1, from the recommended rate of ammonium sulfate), either solely or in combination with organic compost in addition to treatment fully fertilized with only organic compost, on yield, and nutrients (NPK) uptake by grains and straw of wheat (Triticum aestivum L., Sakha 93). All fertilization treatments were applied with or without bacterial (biofertilizer) inoculation. In this respect, Azospirillum brasilense Sp. 245 strain inoculum was used as biofertilizer. After drying, seeds were inoculated with cultural inoculants based on A. brasilense. The experiment had a completely randomized block design with three replicates with $10.5 \mathrm{~m} 2$ each, where nitrogen fertilizer rates and forms were randomly distributed in the main plot and inoculation treatments randomly distributed in the subplot. Experimental soil was classified as sandy clay loam texture. Some of physico-chemical characteristics of the experimental soil are presented in Table 1. Soil physical and chemical analyses were carried out according to Carter and Gregorich (2008). 
Table 1. Some of physico-chemical characteristics of the experimental soil.

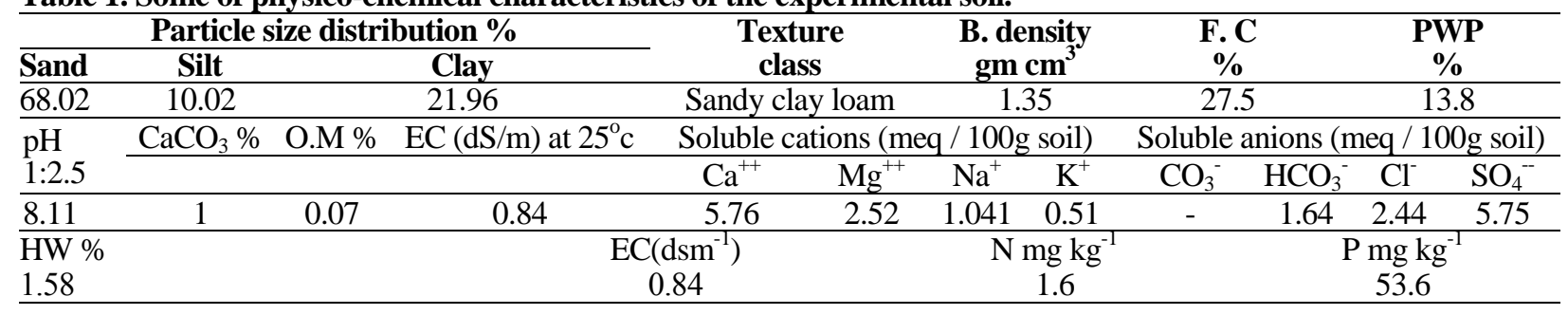

Basal recommended rates of phosphorus and potassium were applied and thoroughly mixed into the soil in preparation stage before cultivation. Phosphorus was applied at $100 \mathrm{~kg} \mathrm{P}$ fed $^{-1}$ as super-phosphate while potassium was added at $50 \mathrm{~kg} \mathrm{~K}$ fed $^{-1}$ as potassium sulfate. Organic compost was added at different rates equal to those of mineral fertilizer-N according to its contents of nitrogen in the composted form. Compost chemical constituents were determined according to Carter and Gregorich (2008) and presented in Table 2.

Table 2. Some chemical characteristics of composted organic materials.

\begin{tabular}{lc}
\hline \multicolumn{1}{c}{ Compost } \\
\hline Determinations & Value \\
\hline PH $(1: 5)$ & 6.70 \\
E.C $\left(\mathrm{dS} \mathrm{m}^{-1}\right)(1: 2.5)$ & 12.70 \\
C/N ratio & 12.62 \\
O.M \% & 56.89 \\
N\% & 2.83 \\
P\% & 0.84 \\
K\% & 0.692 \\
\hline Microelements $\mu \mathrm{g} \mathrm{g}^{-1}$ & \\
Fe & 2897.50 \\
Cu & 212.25 \\
Mn & 137.83 \\
Zn & 155.08 \\
\hline
\end{tabular}

Micro-plot with $1 \mathrm{~m} 2$ area was designed and constructed in each treatment plot $(10.5 \mathrm{~m} 2,3 \mathrm{~m} \mathrm{x} 3.5 \mathrm{~m})$ and received the certain rates of mineral nitrogen in $15 \mathrm{~N}$ labeled ammonium sulfate form with $3 \% 15 \mathrm{~N}$ atom excess. Rest of the plot area was fertilized with ordinary ammonium sulfate at rates of 120, 90 and $30 \mathrm{~kg} \mathrm{~N}$ fed-1 equal to percentages mentioned above. Plants grown on micro-plots were used for collection of $15 \mathrm{~N} / 14 \mathrm{~N}$ ratio analysis. Determination of $15 \mathrm{~N} / 14 \mathrm{~N}$ ratio was carried out using NOI-6PC emission spectrometer and standard equations reported in training TECDOC no. 14, IAEA (2001), were used to determine nitrogen derived from fertilizer (Ndff), organic (Ndforg), air (Ndfa), nitrogen use efficiency (NUE\%) and fertilizer nitrogen remained in soil after harvest ( $\mathrm{N}$ rem. soil).

Equations used:

$$
\% \mathrm{Ndff}=\frac{\%{ }^{15} \mathrm{~N} \text { atom excess of plant }}{\%{ }^{15} \mathrm{~N} \text { atom excess of fertilizer }}
$$

Nitrogen yield derived from fertilizer $\left(\mathrm{kg} \mathrm{fed}^{-1}\right)$

$$
\begin{aligned}
& \text { Nydff }=\% \text { Ndff } x \text { total } \mathbf{N} \text { uptake. } \\
& { }^{15} \mathrm{~N} \% \text { atom excess in organic treated sample } \\
& \% \mathrm{Ndforg}=\left(1-\mathrm{-a}-{ }^{15} \mathrm{~N} \%\right. \text { atom excess in untreated sample } \\
& \% \text { FUE }=\text { - Nydff } \\
& 15 \mathrm{~N} \% \text { a.e. in soil sample } \\
& \text { Fertilizer-N\% remained in soil = -..--..-- } \\
& 15 \mathrm{~N} \% \text { a.e. in added fertilizer }
\end{aligned}
$$

Plant samples were collected at harvest time, separated into straw and grains. Samples were oven dried and straw dry matter and grain yields were recorded. Plant parts were subjected to wet digestion and aliquot was prepared for chemical analysis. Nitrogen was determined by microKjeldahl, $\mathrm{P}$ was determined by spectrophotometer and $\mathrm{K}$ by flame photometer according to Estefan et al., (2013).

Analysis of variance (ANOVA) for the final data obtained in the present study was carried out and Least Significant Differences (LSD) among the means of various treatments followed by Duncan's multiple range test (DMRT) was applied at 5\% level according to SAS (2002).

\section{RESULTS AND DISCUSSION}

\section{Grain and straw yield:-}

Wheat grain and straw yields were significantly affected by nitrogen fertilizer rates where grains showed slight increase with application of $100 \% \mathrm{~N}$ rate comparing to either $75 \%$ or $25 \% \mathrm{~N}$ rate. Similar trend was noticed with straw yield of inoculated plants (Table 3). In this regard, inoculated plants fully fertilized with organic compost yielded grains and straw nearly closed to those treated with $75 \%$ mineral-N rate. Combined treatments of mineral and organic-N reflected yield of grains and straw nearly closed to those of $100 \%$ and $75 \%$ mineral-N rates or those of fully fertilized with organic compost. The highest values of grains and straw yields were recorded with application of $100 \%$ mineral-N and combined of $25 \%$ mineral plus $75 \%$ organic compost. In case of the un-inoculated plants, similar trends were noticed but lower than those recorded with the inoculated plants. In other turn, inoculation of wheat plants enhanced the growth and grain yield. In general, the increase

\begin{tabular}{|c|c|c|c|}
\hline \multirow{3}{*}{ Treatments } & \multicolumn{3}{|c|}{ Biofertilizer } \\
\hline & Inoculated & \multicolumn{2}{|c|}{ Un-inoculated } \\
\hline & Grain Straw & Grain & Straw \\
\hline Mineral-N \% & \multicolumn{3}{|c|}{${\text { Dry weight } \mathrm{Mg} \mathrm{fed}^{-1}}$} \\
\hline 100 & $2.169 \mathrm{a} \quad 3.004 \mathrm{a}$ & $1.778 \mathrm{a}$ & $2.525 \mathrm{ab}$ \\
\hline 75 & $2.002 \mathrm{~b} 2.953 \mathrm{ab}$ & $1.697 \mathrm{ab}$ & $2.461 \mathrm{ab}$ \\
\hline 25 & $1.792 \mathrm{ab} 2.500 \mathrm{~b}$ & $1.433 \mathrm{~b}$ & $2.049 \mathrm{~b}$ \\
\hline Organic compost $100 \%$ & $1.919 a b 2.757 a b$ & $1.669 \mathrm{ab}$ & $2.356 \mathrm{ab}$ \\
\hline$\%$ Mineral+\%compost & & & \\
\hline $75 \mathrm{M}+25 \mathrm{C}$ & $1.921 \mathrm{ab} \quad 2.710 \mathrm{ab}$ & $1.562 \mathrm{ab}$ & $2.203 \mathrm{ab}$ \\
\hline $25 \mathrm{M}+75 \mathrm{C}$ & $2.876 \mathrm{ab}$ & $1.803 \mathrm{a}$ & $2.632 \mathrm{a}$ \\
\hline
\end{tabular}
of grain and straw yields as affected by bacterial inoculation was around $20-25 \%$ higher than those of the un-inoculated plants.

Table 3. Grain yield and straw dry matter $\left({ }^{*} \mathrm{Mg} \mathrm{fed}^{-1}\right)$ of wheat plants treated with different rates of mineral $\mathbf{N}$ fertilizer and organic compost with or without Azospirillum inoculation.

At maturity of wheat crop, Naiman et al., (2009) noted that the dry weight of aerial parts did not increase with 
the addition of urea fertilizer, but did so with inoculation. It was observed that Azospirillum produced significant $(p \leq$ 0.05 ) increases of $20 \%$ when compared to the un-inoculated plants. Also, they indicated that grain yield was increased at range of 17 to $19 \%$, according to Azospirillum ssp., relative to the control without inoculation and fertilization. In the same time, the $\mathrm{N}$-fertilization (Control $\mathrm{CF}$ ) had increased the plant attributes by about $13 \%$. Combination of $\mathrm{N}$-fertilization and inoculation resulted in an average increase with respect to the chemical fertilizer control treatment (CF) by about $7 \%$. Yield increases due to $\mathrm{N}$-fertilization and plant growth promoting rhizobacteria (PGPR) inoculation were $13 \%$ and $14 \%$, respectively. However, all these effects were not significant at the $p \leq 0.05$ level. Consequently, they explained that the increase in both aerial and root biomass due to Azospirillum inoculation could have a significant effect on soil quality. Although the grain yield increases were not significant, they represent important earnings for the farmer whom advised to use PGPR inoculation to obtain the same yield increase reached with $45 \mathrm{~kg} \mathrm{ha}^{-1}$ of urea. Sometimes, neither $\mathrm{N}$-fertilization nor PGPR inoculation have the expected responses. Therefore, they advised the necessary to improve the efficiency level of such agricultural practices.

In accordance, Badr et al., (2016) found an increase in wheat (Sakha 93) growth parameters, i.e. plant height $(\mathrm{cm})$, flag leaf area $(\mathrm{cm})$, dry matter $\left(\mathrm{g} \mathrm{m}^{2}\right)$, number of spikes $\mathrm{m}^{2}$, grain, straw, biological yield(ton fed ${ }^{-1}$ ), and weight of 1000 grain, by increasing nitrogen fertilizer levels up to 100 $\mathrm{kg} \mathrm{N} \mathrm{fed}{ }^{-1}$. Also, they reported an enhancement of wheat growth and grain yield of inoculated plants with cerialin (commercial biofertilizer) by about $6 \%$ relative to the uninoculated one. In comparison with us, these increments in grain yield were very low.

In contrast, Rodrigues et al., (2000) proved that inoculation with Azospirillum brasilense strain 245 has no effect on grain yield of wheat but attributed the increment in yield to the amount of mineral nitrogen added.

Nitrogen uptake:-

Nitrogen uptake by inoculated or un-inoculated plants was significantly varied according to nitrogen fertilizer levels and forms (Table 4). Nitrogen uptake by grains and straw of inoculated plants treated with $100 \%$ and $75 \%$ rates were significantly higher than those recorded with $25 \% \mathrm{~N}$ rate. Values induced by application of high rates were nearly closed to each other. Application of $100 \%$ organic compost resulted in N uptake values slightly higher than $100 \%$ mineral nitrogen rate. Combined treatment of $75 \% \mathrm{M}+25 \% \mathrm{C}$ induced slight decrease in $\mathrm{N}$ uptake by grains and straw as compared to high rates of mineral nitrogen or fully organic fertilized plants. The highest values of $\mathrm{N}$ uptake by grains or straw were detected with combined treatment of $25 \% \mathrm{M}+75 \% \mathrm{C}$, while the lowest one was recorded with application of quarter $\mathrm{N}$ rate. Similar trends but to lower extent were noticed with the un-inoculated plants. Inoculation with Azospirillum brasilense induced an enhancement of nitrogen uptake by plants. This proved the synergistic effect of PGPR genera on plant growth and consequently the nutritional status. In conclusion, combined treatment with one quarter mineral $\mathrm{N}$ plus $3 / 4$ organic compost and the moderate rate of $\mathrm{N}$ mineral fertilizer as well as fully organic treatment could be selected and recommended as the best fertilization treatments.
Table 4. Nitrogen uptake by grain and straw $\left(\mathrm{kg} \mathrm{N} \mathrm{fed}^{-1}\right)$ of wheat plants treated with different rates of mineral $\mathbf{N}$ fertilizer and organic compost with or without Azospirillum inoculation.

\begin{tabular}{|c|c|c|c|c|}
\hline \multirow{3}{*}{ Treatments } & \multicolumn{4}{|c|}{ Biofertilizer } \\
\hline & \multicolumn{2}{|c|}{ Inoculated } & \multicolumn{2}{|c|}{ Un-inoculated } \\
\hline & Grain & Straw & Grain & Straw \\
\hline Mineral-N \% & \multicolumn{4}{|c|}{$\mathrm{N}$ uptake $\mathrm{kg} \mathrm{fed}^{-1}$} \\
\hline 100 & $17.4 \mathrm{ab}$ & $135.9 \mathrm{~b}$ & $13.9 \mathrm{c}$ & $111.5 b$ \\
\hline 75 & $18.0 \mathrm{ab}$ & $136.0 \mathrm{~b}$ & $14.3 \mathrm{c}$ & $114.3 b$ \\
\hline 25 & $6.6 c$ & $50.8 \mathrm{~cd}$ & $5.2 \mathrm{~cd}$ & $41.3 \mathrm{~d}$ \\
\hline Organi & $19.8 \mathrm{ab}$ & $159.5 \mathrm{ab}$ & $16.2 \mathrm{c}$ & $129.7 b$ \\
\hline $1+\%$ & & & & \\
\hline $5 \mathrm{M}$ & 14.9 & $118.8 \mathrm{c}$ & $11.8 \mathrm{c}$ & $94.3 b c$ \\
\hline $25 \mathrm{M}+75 \mathrm{C}$ & $28.6 \mathrm{a}$ & $230.5 \mathrm{a}$ & $23.6 \mathrm{a}$ & $188.9 \mathrm{a}$ \\
\hline
\end{tabular}

Means in the same column followed by the same letter are not significantly different at $p \leq 0.05$.

\section{Phosphorus uptake:-}

Phosphorus uptake by either grains or straw doesn't vary according to nitrogen fertilization levels or types (Table 5). Results proved that inoculation only has an effective role in enhancing $\mathrm{P}$ uptake by organs of inoculated plats comparable to the un-inoculated plants. Slight differences in $\mathrm{P}$ uptake by straw as affected by $\mathrm{N}$ fertilization treatments were noticed with both inoculated and un-inoculated plants. In this respect, treatment of $3 / 4$ mineral $N$ dose plus quarter of organic compost resulted in the best $\mathrm{P}$ value uptake by inoculated or un-inoculated plants.

Table 5. Phosphorus uptake by grain and straw (kg P fed $^{-1}$ ) of wheat plants treated with different rates of mineral $\mathbf{N}$ fertilizer and organic compost with or without Azospirillum inoculation.

\begin{tabular}{|c|c|c|c|c|}
\hline \multirow{3}{*}{ Treatments } & \multicolumn{4}{|c|}{ Biofertilizer } \\
\hline & \multicolumn{2}{|c|}{ Inoculated } & \multicolumn{2}{|c|}{ Un-inoculated } \\
\hline & Grain & Straw & Grain & Straw \\
\hline Mineral-N \% & \multicolumn{4}{|c|}{ P uptake kg fed ${ }^{-1}$} \\
\hline 100 & $2.6 \mathrm{~b}$ & $20.6 b$ & $2.4 \mathrm{~b}$ & $19.3 \mathrm{a}$ \\
\hline 75 & $2.2 \mathrm{~b}$ & $17.7 b c$ & $2.1 b$ & $16.9 \mathrm{~b}$ \\
\hline 25 & $1.9 \mathrm{~b}$ & $15.4 b c$ & $1.8 \mathrm{~b}$ & $14.6 \mathrm{bc}$ \\
\hline Organic compost $100 \%$ & $2.1 \mathrm{~b}$ & $16.7 \mathrm{bc}$ & $2.0 \mathrm{~b}$ & $15.6 \mathrm{~b}$ \\
\hline$\%$ Mineral+\%compost & & & & \\
\hline $75 \mathrm{M}+25 \mathrm{C}$ & $2.5 b$ & $21.4 b$ & $2.4 \mathrm{~b}$ & $19.5 \mathrm{a}$ \\
\hline $25 \mathrm{M}+75 \mathrm{C}$ & $2.3 b$ & $18.7 \mathrm{bc}$ & $2.2 \mathrm{~b}$ & $17.2 \mathrm{~b}$ \\
\hline
\end{tabular}

Means in the same column followed by the same letter are not significantly different at $p \leq 0.05$.

\section{Potassium uptake:-}

It seems that nitrogen fertilizer levels added in mineral or organic form was significantly affected the changes of potassium uptake by grains and straw of wheat plants either inoculated or un-inoculated with Azospirillum strain (Table 6). Potassium uptake by grains and straw tended to increase with increasing nitrogen fertilizer levels. This phenomenon was true under inoculated and the un-inoculated plants. In this respect, there was no significant difference between inoculated and the un-inoculated plants. Plants fully treated with organic compost achieved $\mathrm{K}$ uptake values nearly closed to those induced by application of $75 \%$ of mineral nitrogen rate. Similar results, but to somewhat low extent were detected with application of combined treatment of $75 \%$ mineral-N plus $25 \%$ compost. On the other hand, the highest values of $\mathrm{K}$ uptake by grains and straw were induced by combined treatment of $25 \%$ mineral-N plus $75 \%$ compost. Generally, potassium uptake was significantly positively affected by increasing nitrogen fertilizer rates and organic compost combined with low level of mineral nitrogen 
fertilizer. On the other hand, bacterial inoculation has no significant effect in this subject.

Table 6. Potassium uptake by grain and straw (kg K fed $^{-1}$ ) of wheat plants treated with different rates of mineral $\mathbf{N}$ fertilizer and organic compost with or without Azospirillum inoculation.

\begin{tabular}{|c|c|c|c|}
\hline \multirow{3}{*}{ Treatments } & \multicolumn{3}{|c|}{ Biofertilizer } \\
\hline & Inoculated & \multicolumn{2}{|c|}{ Un-inoculated } \\
\hline & Grain Straw & Grain & Straw \\
\hline Mineral-N \% & \multicolumn{3}{|c|}{ Dry weight $\mathrm{kg} \mathrm{fed}^{-1}$} \\
\hline 100 & $26.8 \mathrm{ab} \quad 214.1 \mathrm{~b}$ & $25.5 b$ & $203.9 b$ \\
\hline 75 & $187.9 \mathrm{bc}$ & $22.8 \mathrm{~b}$ & $182.4 \mathrm{bc}$ \\
\hline 25 & $114.4 \mathrm{c}$ & $13.6 \mathrm{c}$ & $108.4 \mathrm{~cd}$ \\
\hline Organic compost $100 \%$ & $180.3 \mathrm{bc}$ & $22.0 \mathrm{~b}$ & $176.4 \mathrm{bc}$ \\
\hline \%Mineral+\%compost & & & \\
\hline $75 \mathrm{M}+25 \mathrm{C}$ & $156.4 \mathrm{bc}$ & $18.4 \mathrm{bc}$ & $147.1 \mathrm{c}$ \\
\hline $25 \mathrm{M}+75 \mathrm{C}$ & $272.3 \mathrm{a}$ & $33.3 \mathrm{a}$ & 266.1a \\
\hline
\end{tabular}

Means in the same column followed by the same letter are not significantly different at $\boldsymbol{p} \leq \mathbf{0 . 0 5}$.

Nitrogen, phosphorus and potassium uptake by grains of wheat (Sakha 93) were significantly increased by

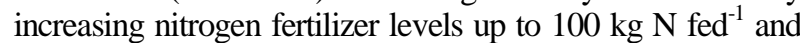
also, positively affected by inoculation with Azospirillum lipoferum (cerialin biofertilizer) under calcareous light soil conditions (El-Wakil et al., 2004; Wu et al., 2005; Badr et al. 2016). Synergistic effect of Azospirillum inoculation on nutrient uptake may be attributed to nitrogen supplemented via free N2-fixation and improvement of release of sparingly soluble elements in soil through excretion of organic acids and hormones like gibberellins, indole acetic acid and cytokinins (Hussein and Radwan 2001;Badr et al., 2015) These hormones could modify root morphology and physiology resulting in more efficient absorption of available nutrients from the soil as affected by fertilization levels and bacterial inoculation (Hussein and Radwan 2001; Ali, et al., 2002; Wu et al., 2005; Koocheki, et al., 2008). In the same direction, Askary et al., (2009) recorded similar effect of single inoculation with Azospirillum that produced significantly higher grain yield by about $29 \%$ which contains more $\mathrm{N}(22.8 \%), \mathrm{P}(59.5 \%)$ and $\mathrm{K}(34 \%)$ comparable to those of the un-inoculated wheat plants. Reversible trend was noticed by Rodrigues et al., (2000) who indicated no significant difference in nitrogen content between inoculated and the un-inoculated wheat plants. They attributed increases in grain and straw nitrogen content only to changes in nitrogen rates added to plants.

Dealing with phosphorus, Lemanowicz et al., (2014) reported that the highest content of available phosphorus (91.58 $\mathrm{mg} \mathrm{P} \mathrm{kg}^{-1}$ ) was reported in the soil amended with farmyard manure at the rate of $60 \mathrm{tha}^{-1}$, where it means that the mobility of phosphorus was increased with farmyard manure applied at the rate of $60 \mathrm{t} \mathrm{ha}^{-1}$ and mineral nitrogen at the rate of $120 \mathrm{~kg} \mathrm{~N} \mathrm{ha}^{-1}$. This also, reflected the increase of acid phosphatase activity with increasing mineral nitrogen rates. Absence of proper crop rotation and mineral nitrogen and organic fertilization may lead to a decrease in the soil organic matter content due to the predominance of mineralization processes (Slowińska-Jurkiewicz et al., 2013), and this may delayed the biological activity and passively affect the dynamics of nutrients in the soil. Concerning inoculation effect, El-Komy (2005) found both phosphorus and potassium uptake by wheat plants inoculated with Azospirillum lipoferum either solely or in combination with Bacillus megaterium was higher than those of the uninoculated plants. These results are in contrast with those we have. They attributed increments in nitrogen, phosphorus and potassium contents in wheat grain and biomass to enhancement of solubilization activities and other mechanisms like nitrogen fixation, hormonal effects and enhancement of soil nutrients uptake. Similar explanations were pointed out earlier (El-Komy et al., 2003).

\section{Nitrogen derived from fertilizer (Ndff):-}

Amounts of nitrogen derived from fertilizer by grains of inoculated plants tended to decrease with reduction in $\mathrm{N}$ fertilizer rates. Similar trend, but to somewhat higher values was detected with Ndff by straw (Table 7). Percentages of Ndff were higher with grains than straw. Addition of compost in combination with mineral fertilizer seems to be act as enhancer for nitrogen portion derived by either grains or straw from mineral-N form. This was more obvious with application of $25 \%$ mineral plus $75 \%$ compost in case of Ndff by grains while reverse was noticed in case of Ndff by straw where combination of $75 \%$ mineral nitrogen plus $25 \%$ compost was the best. Nitrogen derived by grains and straw of the uninoculated plants were slightly different but still near close to those recorded with the inoculated plants.

\section{Nitrogen derived from air (Ndfa):-}

Inoculated plants compensated remarkable amounts of nitrogen via $\mathrm{N}_{2}$-fixation. This phenomenon was more obvious with Ndfa by straw. Ndfa values were severely negatively affected by reduction in nitrogen fertilizer rates. Combined treatments of compost and mineral fertilizer achieved moderate amounts of nitrogen fixed and released to the inoculated plants. Low amounts of nitrogen released from compost were derived to grains of inoculated and uninoculated plants but it increases with increase of compost component in the combined treatments. The Ndforg values were nearly similar in grains of both inoculated and the uninoculated plants. Similar trend, but to higher extent, was noticed with Ndforg derived to straw.

Similar contributions to BNF by wheat was earlier observed by et al., Araújo et al., (2015) whom reported that Azospirillum brasilense inoculated corn achieved higher BNF values than those recorded with Herpspirillum seropedicae strain accounted for $19.4 \%$ and 9.5\%, respectively. It seems that BNF contributions were related to corn cultivars where it ranged from 12 up to $33 \%$ with series of commercial corn cultivars using ${ }^{15} \mathrm{~N}$ isotope dilution technique (Montanez et al., 2009).

\section{Nitrogen use efficiency ( $\%$ NUE):-}

As indicator to benefits from mineral fertilizer, NUE by either grains or straw of the inoculated plants were tended to increase with decreasing $\mathrm{N}$ fertilizer rates either individually or in combination with compost. The highest NUE was recorded with combined treatment of $25 \%$ mineral-N plus $75 \%$ compost indicating the synergistic effect of organic compost on enhancement of NUE by grains. This holds true with both inoculated and the uninoculated plants with slight differences. Similar trends but in higher percentages were observed with NUE by straw of either inoculated or the uninoculated plants.

In harmony, Ahmad et al., (2017) concluded that impregnation of diammonium phosphate (DAP) and urea granules with plant growth promoting bacteria (PGPB) (Bacillus sp. strain KAP6)-inoculated compost or humic acid (powdered) is very effective in enhancing nutrient use efficiency of wheat. They indicated the best NUE with the application of DAP and urea coated with $2 \mathrm{~g}$ inoculated compost $100 \mathrm{~g}^{-1}$ mineral fertilizer. In the study of Araújo et 
al., (2015) with corn plants, the highest NUE were achieved by application of $30 \mathrm{~kg} \mathrm{~N} \mathrm{ha}^{-1}$ and inoculated with Azospirillum brasilense and Herbaspirillum seropedicae. They found that NUE was decreased with increasing nitrogen fertilizer rates. It was found that NUE was varied among cereal crops due to soil and climate change, type of fertilizer, management cultivation practices and losses mechanisms (Duete et al., 2008; Lara-Cabezas et al., 2004; Figueiredo et al., 2005).

Table 7. Portions, values of nitrogen derived from fertilizer (Ndff), air (Ndfa), organic compost (Ndforg) and nitrogen use efficiency (\%NUE) by barley organs as affected by organic/mineral-N, rates and bacterial inoculation.

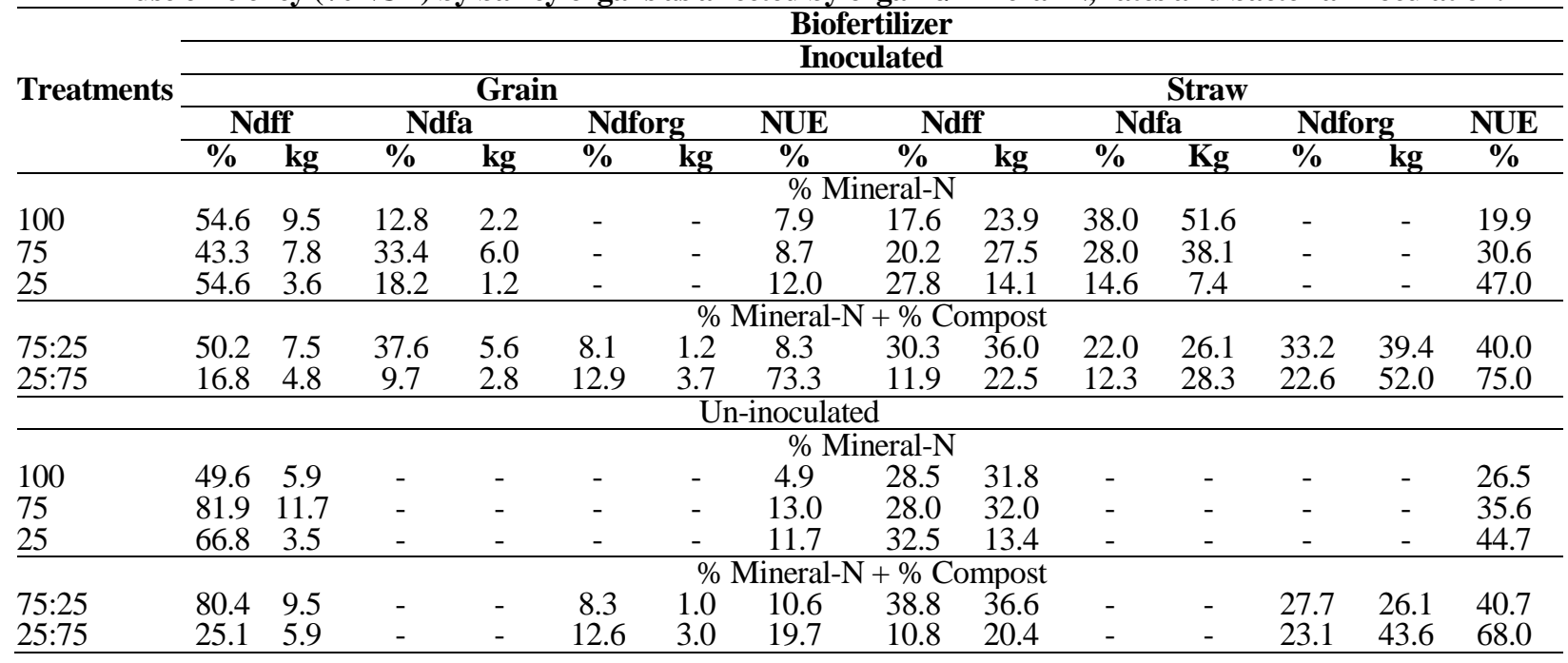

Nitrogen remained in soil $\left(\mathbf{N}_{\text {rem. soil }}\right)$ :-

Nitrogen remained in soil after harvest was severely decreased with decreasing $\mathrm{N}$ fertilizer rate from $100 \%$ to $25 \%$ of the recommended rate (Fig. 1). Comparing to sole addition of $75 \%$ and $25 \%$ mineral nitrogen, the combination with compost resulted in more nitrogen was residue in soil after harvest. This may be attributed to the priming effect of organic additions. Also, some of mineral nitrogen may be cohered with organic compost then released in soil later on. In general, nitrogen fertilizer remained in soil was to some extent higher under the uninoculated treatment than those of inoculated ones except the treatment of $25 \%$ mineral-N plus $75 \%$ compost where values of inoculated and the uninoculated treatments were nearly the same.

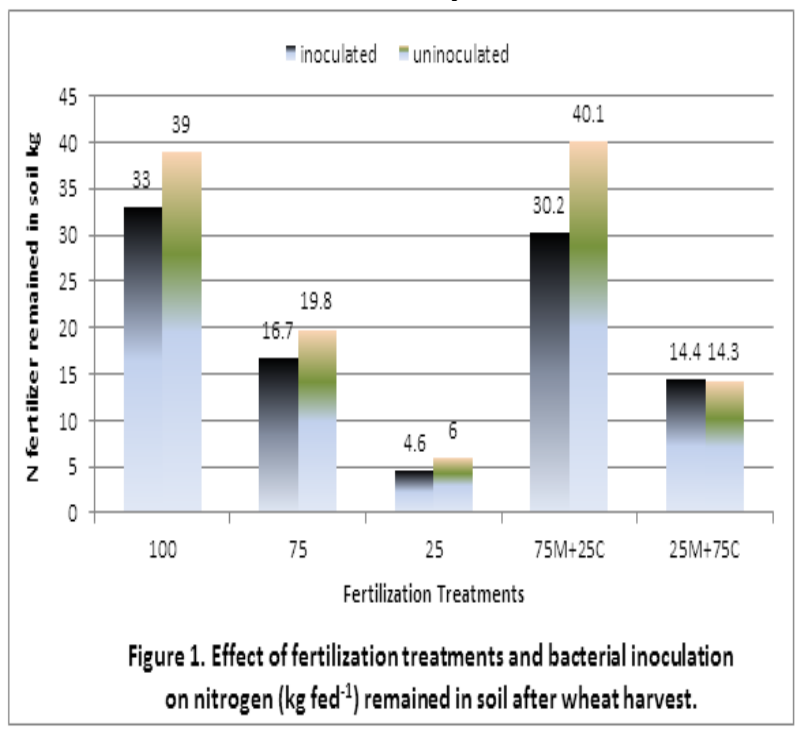

\section{Fertilizer nitrogen balance:-}

Fertilizer added as mineral form was divided into different portions, i.e. those derived from fertilizer, residue in soil after harvest and those lost from media by any loss mechanism (Table 8). Portion of nitrogen derived by whole plant from fertilizer and those remained in soil tended to decrease with decline of addition rate when applied individually. This was accompanied with high $\mathrm{N}$ losses which behave similarly to Ndff and $\mathrm{N}$ remained in soil. At medium (75\%) to low $(25 \%)$ nitrogen fertilizer rates, plant derived more nitrogen from fertilizer and left less nitrogen in the soil comparing to high $\mathrm{N}$ rate. Combined treatment of mineral and organic compost showed higher Ndff and less $\mathrm{N}$ losses as compared to the same mineral $\mathrm{N}$ rates applied individually. These trends of inoculated and the uninoculated treatments were almost the same. It was appeared that application of medium to low mineral $\mathrm{N}$ in combination with organic compost lowered the portion of $\mathrm{N}$ losses and achieved positive $\mathrm{N}$ balance. This phenomenon was more vigorous with combined treatment of $75 \%$ mineral plus $25 \%$ organic compost under the uninoculated treatment. Negative $\mathrm{N}$ balances were observed with sole addition of mineral nitrogen and tended to decline with reduction in nitrogen fertilizer rates. These trends were lower in case of the uninoculated plants than inoculated one. This may be attributed to portion of $\mathrm{N}$ derived from air by inoculated plants while the uninoculated ones seems to be more dependent on mineral fraction therefore it derives more nitrogen from mineral $\mathrm{N}$ that decreases nitrogen loss.

In this regard, Sieling et al., (2006) indicated that wheat significantly took up more $\mathrm{N}$ in the grain and left less $\mathrm{N}$ in the system after harvest (residual $\mathrm{N}(\mathrm{Nres})=\mathrm{N}$ supply $-\mathrm{N}$ uptake in the grain) (64 $\left.\mathrm{kg} \mathrm{Nha}^{-1}\right)$ than barley $\left(96 \mathrm{~kg} \mathrm{Nha}^{-1}\right.$ ) and oil seed rape (OSR) $\left(92 \mathrm{~kg} \mathrm{Nha}^{-1}\right) . \mathrm{N}$ lost via leaching was lowest after barley under OSR and highest after OSR under winter wheat. In addition, they found an increase in $\mathrm{N}$ uptake by wheat grain of plants treated with slurry, but also residual nitrogen (Nres) after harvest and $\mathrm{N}$ leaching. Without slurry, $\mathrm{N}$ balance was negative, whereas two slurry applications led to an $\mathrm{N}$ surplus of $70 \mathrm{~kg} \mathrm{Nha}^{-1}$ annually. Mineral $\mathrm{N}$ fertilization induced increases in $\mathrm{N}$ uptake by grain from $67 \mathrm{~kg} \mathrm{~N}^{-1}$ without mineral $\mathrm{N}$ up to $141 \mathrm{~kg} \mathrm{~N} \mathrm{ha}^{-1}$ annually, if $240 \mathrm{~kg}$ $\mathrm{N} \mathrm{ha}{ }^{-1}$ were applied each year. The corresponding $\mathrm{N}$ 
balance ranged between -28 and $+98 \mathrm{~kg} \mathrm{~N}^{-1}$ annually. The combination of slurry and mineral $\mathrm{N}$ revealed more pronounced effects of mineral $\mathrm{N}$ fertilization on $\mathrm{N}$ uptake by grain compared to individual slurry application, whereas slurry led to higher $\mathrm{N}$ losses. These findings were more or less in harmony with those obtained in our work.

Table 8. Fertilizer nitrogen balance under mineralorganic fertilization and bacterial inoculation treatment.

\begin{tabular}{|c|c|c|c|c|}
\hline \multirow{5}{*}{ Treatments } & \multicolumn{4}{|c|}{ Biofertilizer } \\
\hline & \multicolumn{4}{|c|}{ Inoculated } \\
\hline & \multicolumn{4}{|c|}{ Whole plant (grain + straw) } \\
\hline & Ndff & $\mathbf{N}_{\text {rem. }}$ & $\mathbf{N}_{\text {loss }}$ & $\mathbf{N}_{\text {balance }}$ \\
\hline & \multicolumn{4}{|c|}{$\%$ Mineral-N } \\
\hline 100 & 33.4 & 33.0 & 53.6 & -20.6 \\
\hline 75 & 35.3 & 16.7 & 38.0 & -21.3 \\
\hline 25 & 17.7 & 4.6 & 7.7 & -3.1 \\
\hline & \multicolumn{4}{|c|}{$\%$ Mineral-N + \% Compost } \\
\hline $75: 25$ & 43.5 & 30.2 & 16.3 & 13.9 \\
\hline $25: 75$ & 27.3 & 1.4 & 1.3 & 0.1 \\
\hline \multicolumn{5}{|c|}{ Un-inoculated } \\
\hline 100 & 37.7 & 39.0 & 43.3 & -4.3 \\
\hline 75 & 43.7 & 19.8 & 26.5 & -6.7 \\
\hline 25 & 16.9 & 6.0 & 7.1 & -1.1 \\
\hline & \multicolumn{4}{|c|}{$\%$ Mineral-N + \% Compost } \\
\hline $75: 25$ & 46.1 & 40.1 & 3.8 & 36.3 \\
\hline $25: 75$ & 26.3 & 1.3 & 2.4 & -1.1 \\
\hline
\end{tabular}

\section{CONCLUSION}

Management of nitrogen nutrient is a limiting factor in wheat production as one of the most strategic crops. Moderate additions resulted in remarkable yield and in the same time reduced nitrogen losses. Also, moderate to low rates of nitrogen were efficiently used by grains and straw. Bacterial inoculation compensated reasonable amounts of nitrogen gained by wheat via biological nitrogen fixation. Organic compost either applied solely or in combination with mineral fertilizer supplemented the crop with amounts of nitrogen nearly closed to those derived from air. In addition, compost enhanced the use of low to moderate rates of mineral nitrogen (NUE). Fertilizer nitrogen balance was positively affected by combination of organic compost and mineral-N. On the other hand, it was negatively affected by sole additions of mineral nitrogen. Organic compost lowered mineral nitrogen losses, enhanced NUE and increased the portion of mineral $\mathrm{n}$ remained in soil after harvest which reflected a positive $\mathrm{N}$ balance. We can conclude that integrated management of mineral nitrogen and organic additives in combination with biofertilizer may act as the most proper strategy that achieved remarkable yield and reducing the environmental risks.

\section{REFERENCES}

Ahmad, S., Imran, M., Hussain, S., Mahmood, S., Hussaine, A. and Hasnain, M. (2017). Bacterial impregnation of mineral fertilizers improves yield and nutrient use efficiency of wheat. J Sci Food Agric, wileyonlinelibrary.com/jsfa, DOI 10.1002/jsfa.8228

Ali, N.A., Darwish, S.D. and Mansour, S.M. (2002). Effect of Azotobacter chroococcum and Azospirillum brasilense inoculation an anhydrous ammonia on root colonization, plant growth and yield of wheat plant under saline alkaline cognition, J. Agric. Sci. Mansoura Univ. Egypt 27 (2002), pp.5575-5591.
Araújo, E. de O., Martins, M.R., Tadeu, A.C., Mercante, F.M. and Urquiaga, S.S. (2015). Effect of nitrogen fertilization associated with diazotrophic bacteria inoculation on nitrogen use efficiency and its biological fixation by corn determined using ${ }^{15} \mathrm{~N}$. African J. Microbiol. Res., 9: 643-650.

Askary, M., Mostajeran, A., Amooaghaei, R. and Mostajeran, M. (2009). Influence of the coinoculation Azospirillum brasilense and Rhizobium meliloti plus 2,4-D on grain yield and N, P, K content of Triticum aestivum (cv. Baccros and Mahdavi). American-Eurasian J. Agric. \& Environ. Sci., 5 (3): 296-307.

Askary, M., Mostajeran A. and Emtiazi, G. (2008). Colonization and nitrogenase activity of Triticum aestivum (cv. Baccross and Mahdavi) to the dual inoculation with Azospirillum brasilense and Rhizobium meliloti plus 2,4-D. Pak. J. Biol. Sci., 11(12): 1541-1550.

Badr, E. A., Afifi, M.H.M. and EL-Dewiny, C.Y. (2016). Effect of bio-fertilization and Nitrogen level on yield, chemical constituents and Nitrogen use efficiency on two wheat cultivars grown under calcareous soil conditions. Inter. J. of ChemTech, Vol.9, ,9: 132-139.

Badr, E.A., Ibrahim, O.M., Tawfik, M.M. and Bahr, A.A. (2015). Management strategy for improving the productivity of wheat in newly reclaimed sandy soil. Inter. J. of Chem Tech Res. Vol.8, No.4, pp 14381445.

Bielińska E.J. and Mocek-Płóciniak A. (2012). Impact of the tillage system on the soil enzymatic activity. Archiv. Environ. Protec., 38(1), 75-82.

Carter, M.R. and Gregorich, E.G. (2008). Soil Sampling and Methods of Analysis. (2nd ed.), CRC Press Taylor \& Francis Group, 6000 Broken Sound Parkway NW, Suite 300 Boca Raton, FL, p. 1224.

Cassán, F. and García de Salamone, I. (2008). Azospirillum sp.: Cell physiology, plant interactions and agronomic research in Argentina. Argentina Association of Microbiology, Argentina, ISBN 978-987-98475-8-9.

Creus, C.M., Sueldo, R.J. and Barassi, C.A. (2004). Water relations and yield in Azospirillum inoculated wheat exposed to drought in the field. Can. J. Bot., 82: 273281.

Duete, R.R.C., Muraoka, T., Silva, E.C., Trivelin, P.C.O. and Ambrosano, E.J. (2008). Management of nitrogen fertilization and use of nitrogen $\left({ }^{15} \mathrm{~N}\right)$ by corn in Red Latosol. J. Soil Sci. 32:161-171.

El-Komy, H.M. (2005). Co-immobilization of Azospirillum lipoferum and Bacillus megaterium for successful phosphorus and nitrogen nutrition of wheat plants. Food Technol. Biotechnol. 43 (1) 19-27.

El-Komy, H.M., Abdel-Samad, H.M. and Abd El-Baki, G.K. (2003). Nitrate reductase in wheat plants grown under water stress and inoculated with Azospirillum spp., Biol. Plant. 46, 281-287.

El-Wakil; A.R. and Abd-Alla, M. M. (2004). Influence of seeding rate and nitrogen fertilization level on yield and its attributes of some wheat cultivars. Egypt. J. Appl. Sci, 19(2): 129-150.

Estefan, G., Sommer, R. and Ryan, J. (2013). Methods of soil, plant and water analysis: A manual for the West Asia and North Africa regions. International Center for Agricultural Research in the Dry Areas (ICARDA), 3 Ed. 
Figueiredo, C.C., Resck, D.V.S., Gomes, A.C., and Urquiaga, S.S.C. (2005). Management systems in nitrogen uptake by corn in Red Latosol in the Cerrado. Search Agrop. Braz. 40: 279-287.

Filipek T. and Skowrońska M. (2009). Optimizations of soil reaction and nutrient managment in Polish agriculture. Adv. Agric. Sci., 1, 25-37.

George T.S., Gregory P.J., Wood M., Read M., and Buresh R.J. (2002). Phosphatase activity and organic acids in the rhizosphere of potential agroforestry species and maize. Soil Biol. Biochem., 34, 1487-1494.

Hussein, H.F. and Radwan, S.M.A. (2001). Effect of biofertilization with different levels of nitrogen and phosphorus on wheat and associated weeds under weed control treatments. Pak. J. Bio. Sci., 4(4): 435441.

IAEA, Vienna (2001). Use of isotope and radiation methods insoil and water management and crop nutrition.Manual.Training course series No. 14. IAEA, Vienna.

Kaczor A. and Łaszcz-Zakorczemna J. (2009). The effect of sulphur and potassium fertilization of barley and rape on the content of available phosphorus, potassium and magnesium in soil. Adv. Agricul. Sci. Probl., 538, 103-110.

Koocheki, A., Jahan, M. and Nassiri Mahallati, M. (2008). Effects of arbuscular mycorrhizal fungi and freeliving nitrogen- fixing bacteria on growth characteristics of corn (Zea mays L.) under organic and conventional cropping systems. Cultivating the Future Based on Science: 2nd Conference of the International Society of Organic Agriculture Research ISOFAR, Modena, Italy, June 18-20, $2008 . \quad$ pp., 336-339.

Krämer S. and Green D.M. (2000). Acid and alkaline phosphatase dynamics and their relationship to soil microclimate in a semiarid woodland. Soil Biol. Biochem., 32, 179-188.

Lara-Cabeza, W.A.R., Trivelin, P.C.O., Kondorfer, G.H., and Pereira, S. (2000). Balance of solid and fluid nitrogen fertilizer in maize crop coverage, tillage system. J. Soil Sci. 24: (2): 363-376.
Lemanowicz, J., Siwik-Ziomek, A. and Koper J. (2014). Effects of farmyard manure and nitrogen fertilizers on mobility of phosphorus and sulphur in wheat and activity of selected hydrolases in soil. Int. Agrophys., 28, 49-55.

Montanez, A., Abreu, C., Gill, P.R., Hardarson, G. and Sicardi, M. (2009). Biological nitrogen fixation in maize (Zea mays L.) by ${ }^{15} \mathrm{~N}$ isotope dilution and identification of associated culturable diazotrophs. Biol. Fert. Soils 45: 253-263.

Naiman, A. D., Latrónico, A. and Garcı de Salamone, I.E. (2009). Inoculation of wheat with Azospirillum brasilense and Pseudomonas fluorescens: Impact on the production and culturable rhizosphere microflora. Europ. J. Soil Biology 45, 44-51.

Naiman, A. D., Latrónico, A., Tovagliari, A., and Garcia de Salamone, I.E. (2007). Impacto de la biofertilización de Trigo sobre la flora bacteriana rizosférica y sus componentes de rendimiento, Revista Argentina de Microbiología 39, 147.

Rodrigues, O., Didonet, A.D., Gouveia, J. and Soares, R.C. (2000). Nitrogen translocation in wheat inoculated with Azospirillum and fertilized with nitrogen. Pesq. Agropec. Bras., Brasilia, v. 35, n. 7, 1473-1481.

SAS. (2002). Statistical Analysis System user's Guide. Version 5, Cary, CN.

Sieling, K., Brase, T. and Svib, V. (2006). Residual effects of different $\mathrm{N}$ fertilizer treatments on growth, $\mathrm{N}$ uptake and yield of oilseed rape, wheat and barley. Europ. J. Agronomy 25, 40-48.

Słowińska-Jurkiewicz A., Bryk M., and Medvedev V.V. (2013). Long-term organic fertilization effect on chernozem structure. Int. Agrophys., 27, 81-87.

Suwara, I., Lenart, S., and Gawrońska-Kulesza, A. (2007). Growth and yeld of winter wheat after 50 years of different fertilization and crop rotation. Acta Agrophysica, 153, 695-704.

Wu, S.C., Cao, Z.H., Li, Z.G., Cheung, K.C. and Wong, M.H. (2005). Effects of biofertilizer containing Nfixer, $\mathrm{P}$ and $\mathrm{K}$ solubilizers and AM fungi on maize growth: a greenhouse trial, Geoderma 125, pp. 155166.

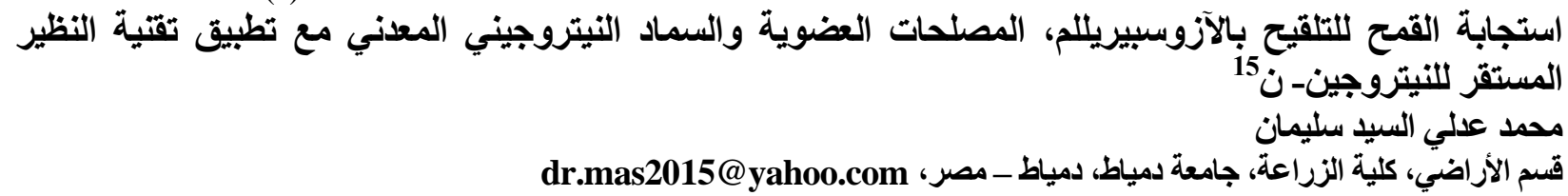

\footnotetext{
القمح من أهم المحاصيل الاستراتيجية كغذاء وعلف. لأهميته، كان الهدف من العمل هو تبيان دور المصادر الآزوتية الكيماوية والعضوية في تمازج مع التلقيح

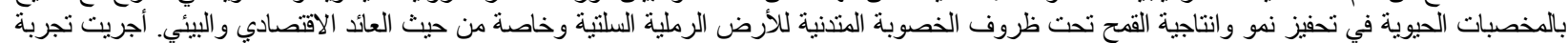

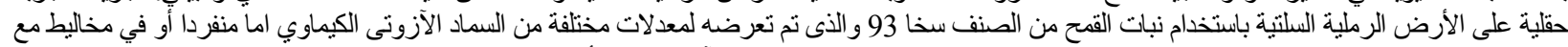

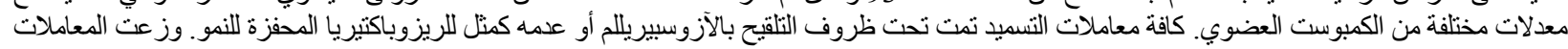

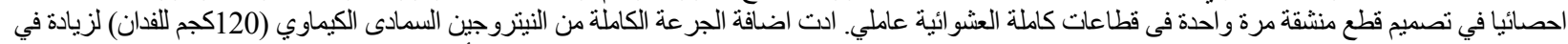

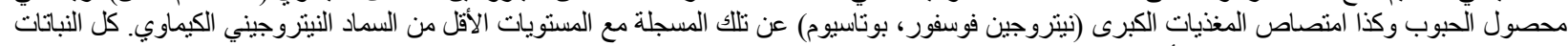

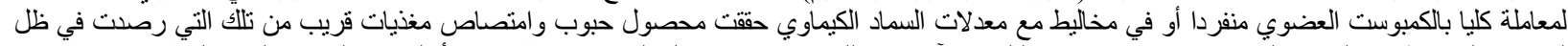

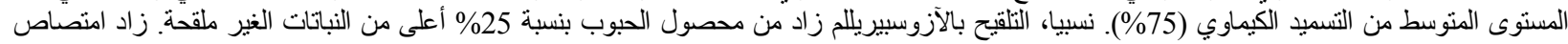

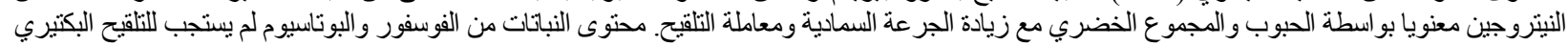

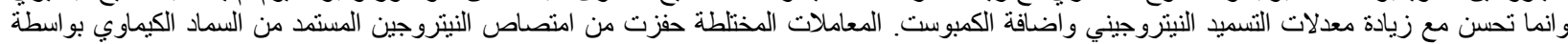

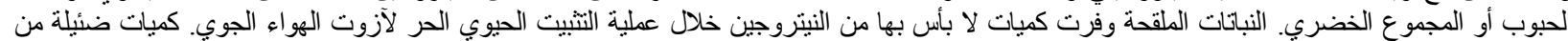

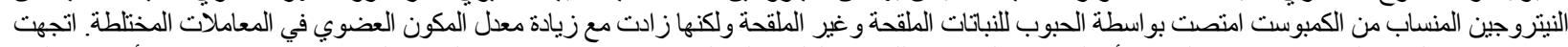

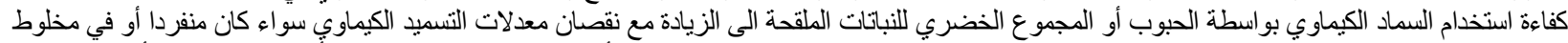

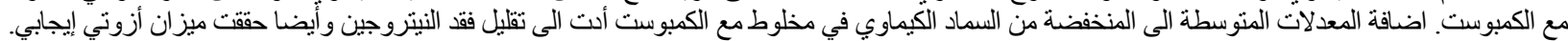

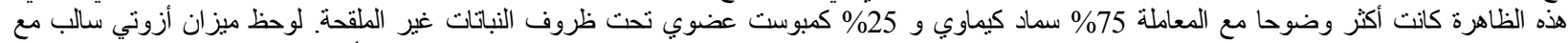

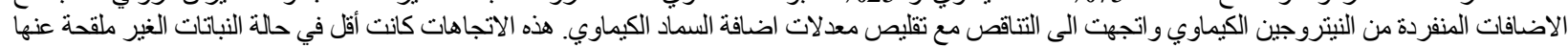
في حالة النباتات الملقحة.
} 